\title{
Comparative Study of Adenosine Deaminase Activity to Biochemical Parameter, Nutritional Status and BMI duringTuberculosis Infection
}

\author{
Dr. Shashikant Agarwal ${ }^{1}$ \\ ${ }^{I}$ Associate Professor, Department of Physiology, Jhalawar Medical College
}

\begin{abstract}
Tuberculosis has emerged as one of the most lethal disease men has faced. Inspite of presence of effective chemotherapy epidemiological data showed world wide rise in incidence especially since AIDS incidence rose steeply. There seems to be a resurgence of both pulmonary and extra pulmonary tuberculosis. The present case study depicted the comparative study of level of ADA activity with several physiological parameters and nutritional status during tuberculosis infection. The data was collected and interpreted at department of Physiology and Department of Medicine Gandhi Medical College, Bhopal.

Keywords: Tuberculosis, chemotherapy, AIDS, ADA, nutritional status
\end{abstract}

The present study was carried out in the department of Physiology and Department of Medicine Gandhi Medical College, Bhopal. The Biochemical investigation was carried out in the department of Biochemistry of the institution. The study comprised of 30 normal healthy control aged 18-48 years and newly diagnosed 30 cases of tuberculous meningitis, 30 cases of tuberculous pleural effusion, 30 cases of tuberculous ascites who volunteered for the study. The study population consisted of 45 men and 45 women with an average age range of 14-70 years. The adenosine deaminase was measured and correlated with various parameters.

TABLE : 1

CHARACTERISTICS OF CONTROL GROUP $(n=30)$

\begin{tabular}{|c|c|c|c|c|c|c|c|c|c|c|}
\hline \multirow[t]{2}{*}{ Parameters } & \multirow{2}{*}{$\begin{array}{c}\text { Age } \\
\text { (in } \\
\text { yrs) }\end{array}$} & \multirow{2}{*}{$\begin{array}{l}\text { Wt } \\
\text { (in } \\
\text { kg) }\end{array}$} & \multirow{2}{*}{$\begin{array}{c}\text { Ht (in } \\
\text { cms) }\end{array}$} & \multirow{2}{*}{$\begin{array}{c}\text { BMI } \\
\left(\mathrm{kg} / \mathrm{m}^{2}\right)\end{array}$} & \multirow{2}{*}{$\begin{array}{c}\mathbf{H b} \\
(\mathbf{g m} \% \\
)\end{array}$} & \multicolumn{2}{|c|}{ B.P. $\mathrm{mmHg}$} & \multirow{2}{*}{$\begin{array}{c}\text { Pluse } \\
\text { Rate } \\
\text { (per } \\
\text { min.) }\end{array}$} & \multirow{2}{*}{$\begin{array}{c}\text { Respirat } \\
\text { ory rate } \\
\text { (per } \\
\text { min.) }\end{array}$} & \multirow{2}{*}{$\begin{array}{c}\text { Serum } \\
\text { ADA } \\
\text { U/L }\end{array}$} \\
\hline & & & & & & Systolic & $\begin{array}{c}\text { Diastoli } \\
\text { c }\end{array}$ & & & \\
\hline Vales & 31.73 & 51. & 155.77 & 21.25 & 13.88 & 120 & 79.66 & 77.93 & 18.73 & 14.05 \\
\hline Mean- & \pm 8.47 & $\begin{array}{c}8 \\
+4 . \\
96\end{array}$ & \pm 4.22 & \pm 1.53 & \pm 0.97 & \pm 5.89 & \pm 3.11 & \pm 8.09 & \pm 2.13 & \pm 4.02 \\
\hline Range & $18-48$ & $\begin{array}{l}42- \\
62\end{array}$ & $\begin{array}{l}148- \\
164\end{array}$ & $\begin{array}{l}18.6- \\
23.8\end{array}$ & $\begin{array}{c}12- \\
15.2\end{array}$ & $110-132$ & $70-86$ & $66-92$ & $14-22$ & $7.8-20.4$ \\
\hline
\end{tabular}

30 normal healthy controls were taken in the age range of $18-48$ yrs. The calculated mean BMI $(21.25 \pm 1.56$ $\left.\mathrm{kg} / \mathrm{m}^{2}\right)$ and estimated $\mathrm{Hb}$ content $(13.88+0.97 \mathrm{gm} \%)$ suggested normal nutritional status of these subjects. The cardio respiratory profile was within the normal limits. Mean serum ADA level measured by ADA MTB kit method was $14.05 \pm 4.02 \mathrm{U} / \mathrm{L}$ which $<30 \mathrm{U} / \mathrm{L}$ hence was considered as normal. Yoneda (1) studied the prevalence of PEM in patients with chronic pulmonary tuberculosis and reported that grade of malnutrition was associated with reduced cell mediated immunity. Hanekom et al. (2) suggested that nutritional status of the tuberculosis patients alter the cytokine responses.

TABLE : 2

CHARACTERISTICS OF STUDY POPULATION

\begin{tabular}{|c|c|c|c|c|}
\hline $\begin{array}{l}\text { S. } \\
\text { No. }\end{array}$ & Parameters & $\begin{array}{c}\text { Tuberculous meningitis } \\
(\mathrm{n}=\mathbf{3 0})\end{array}$ & $\begin{array}{c}\text { Tuberculous Pleural } \\
\text { Effusion }(n=30)\end{array}$ & $\begin{array}{c}\text { Tuberculous ascites } \\
(\mathrm{n}=\mathbf{3 0})\end{array}$ \\
\hline 1 & $\begin{array}{l}\text { Age (yrs.) } \\
\text { Mean } \pm \text { SD } \\
\text { Range }\end{array}$ & $\begin{array}{c}33.1 \pm 11.07 \\
18-60\end{array}$ & $\begin{array}{l}38.77 \pm 12.11 \\
20-60\end{array}$ & $\begin{array}{c}38.43 \pm 12.88 \\
20-60\end{array}$ \\
\hline 2 & $\begin{array}{l}\text { Height }(\mathrm{cm}) \\
\text { Mean } \pm \text { SD } \\
\text { Range }\end{array}$ & $\begin{array}{c}156.47 \pm 4.59 \\
150-164\end{array}$ & $\begin{array}{c}157.6 \pm 3.91 \\
150-165\end{array}$ & $\begin{array}{c}156.6 \pm 4.60 \\
148-165\end{array}$ \\
\hline 3 & $\begin{array}{l}\text { Body weight }(\mathrm{kg}) \\
\text { Mean } \pm \text { SD } \\
\text { Range }\end{array}$ & $\begin{array}{c}44.6 \pm 9.37 \\
30-64\end{array}$ & $\begin{array}{c}43.46 \pm 64 \\
32.8-54\end{array}$ & $\begin{array}{c}44.133 \pm 8.00 \\
32-60\end{array}$ \\
\hline
\end{tabular}




\begin{tabular}{|l|l|c|c|c|}
\hline 4 & Body mass index $\left(\mathrm{kg} / \mathrm{m}^{2}\right)$ & & & \\
& Mean $\pm \mathrm{SD}$ & $18.06 \pm 3.06$ & $17.53 \pm 2.144$ & $17.92 \pm 2.71$ \\
& Range & $12-23.79$ & $14.23-21.92$ & $12.64-22.65$ \\
\hline
\end{tabular}

Age wise classification of study population revealed that the mean age of study group was $36-76 \pm 12.19$ years (range18-60 years).

Body mass index was calculated to assess the nutritional status of the population.

Mean body mass index of study group was $17.84 \pm 2.64 \mathrm{~kg} / \mathrm{m}^{2}$ indicating poor nutritional status of the study population.

TABLE : 3

COMPARISON OF NUTRITIONAL STATUS OF MALE AND FEMALE SUBJECTS

\begin{tabular}{|l|c|c|c|}
\hline Group & $\begin{array}{c}\text { BMI }\left(\mathbf{k g} / \mathbf{m}^{2}\right) \\
\text { Mean } \mathbf{S} \text { S.D. } \\
\text { Range }\end{array}$ & 't' value & 'p' value \\
\hline Male $(\mathrm{n}=45)$ & $19.08 \pm 2.65$ & 5.44 & $<0.001$ \\
& $14.02-23.79$ & & \\
\hline Female $(\mathrm{n}=45)$ & $16.60 \pm 1.99$ & & \\
& $12-20.99$ & & \\
\hline
\end{tabular}

The values of the body mass index calculated revealed that the nutritional status of the majority male subject was normal but the female subjects were categorized as malnourished. The difference in the nutritional status was statistically significant.

The nutritional status as reflected by the Hb levels also suggested that the patients included in the study were nutritionally compromised. Similar findings were reported by Mehta et al. (3) who measured serum albumin and $\mathrm{Hb}$ levels in tuberculosis patients there study concluded that $\mathrm{Hb}$ level is the best predictor of survival. Macallan et al. (4) investigated protein metabolism is patients of pulmonary tuberculosis and reported impaired anabolic response on feeding.

TABLE : 4

PRESENTING COMPLAINTS OF TUBERCULOUS MENINGITIS PATIENTS $(\mathbf{n}=30)$

\begin{tabular}{|c|l|c|c|}
\hline S. No. & Presenting Complaints & No. of cases & Percentage \\
\hline 1 & Headache & 28 & 99.33 \\
\hline 2 & Fever & 30 & 100 \\
\hline 3 & Vomiting & 24 & 80 \\
\hline 4 & Convulsion & 9 & 30 \\
\hline 5 & Altered sensorium & 12 & 40 \\
\hline 6 & Visual disturbances & 1 & 3.33 \\
\hline 7 & Weakness of limbs & 2 & 10 \\
\hline 8 & Strabismus & 3 & 10 \\
\hline 9 & Urinary disturbance & 4 & 13.33 \\
\hline 10 & Difficulty in speech & 2 & 6.66 \\
\hline
\end{tabular}

The observation revealed that majority of the patients suffered from headache, fever and vomiting.

TABLE : 5

PRESENTING COMPLAINTS OF TUBERCULOUS PLEURAL EFFUSION PATIENTS

\begin{tabular}{|c|l|c|c|}
\hline S. No. & Presenting complaints & No. of cases & Percentage \\
\hline 1 & Chest pain & 28 & 93.33 \\
\hline 2 & Cough & 29 & 96.66 \\
\hline 3 & Fever & 27 & 90 \\
\hline 4 & Weight loss & 26 & 86.66 \\
\hline 5 & Loss of appetite & 28 & 93.33 \\
\hline 6 & Breathlessness (Dyspnoea) & 28 & 93.33 \\
\hline 7 & Tiredness & 24 & 80 \\
\hline 8 & Headache & 16 & 53.33 \\
\hline 9 & Night sweats & 22 & 73.33 \\
\hline
\end{tabular}

On detailed clinical examination and history taking it was observed that cough, chest pain, dysponea and loss of appetite were the main symptoms causing distress to the patients. 
Villagas et al. (5) studied 61 patient of tuberculous pleural effusion $71 \%$ patients presented with fever, $31 \%$ with productive cough.

Aguado et al. (6) studied tuberculous peritonitis patients and reported prevalence of abdominal swelling $100 \%$, abdominal pain (98\%). Weight loss $87 \%$, abdominal tenderness $87 \%$.

TABLE : 6

PRESENTING COMPLAINTS OF TUBERCULOUS ASCITES PATIENTS

\begin{tabular}{|c|l|c|c|}
\hline S. No. & Presenting complaints & No. of cases & Percentage \\
\hline 1 & Abdominal complaints & 30 & 100 \\
\hline 2 & Abdominal pain & 28 & 93.33 \\
\hline 3 & Weight loss & 20 & 66.66 \\
\hline 4 & Diarrhoea & 3 & 10 \\
\hline 5 & Constipation & 1 & 3.33 \\
\hline 6 & Fever & 18 & 60 \\
\hline 7 & Tiredness & 16 & 88.88 \\
\hline 8 & Loss of appetite & 20 & 66.66 \\
\hline
\end{tabular}

Abdominal distension and abdominal pain were the chief complaints of tuberculous ascites patients.

TABLE : 7

CARDIORESPIRATORY PROFILE OF THE STUDY POPULATION

\begin{tabular}{|l|l|c|c|c|}
\hline S. No. & Parameters & $\begin{array}{c}\text { Tuberculous } \\
\text { meningitis }(\mathbf{n = 3 0})\end{array}$ & $\begin{array}{c}\text { Tuberculous } \\
\text { ascites }(\mathbf{n}=\mathbf{3 0})\end{array}$ & $\begin{array}{c}\text { Tuberculous } \\
\text { pleural effusion } \\
(\mathbf{n}=\mathbf{3 0})\end{array}$ \\
\hline 1 & $\begin{array}{l}\text { Pulse (per minute) } \\
\text { Mean } \pm \text { S.D. } \\
\text { Range }\end{array}$ & $\begin{array}{c}85.93 \pm 7.07 \\
68-10\end{array}$ & $\begin{array}{c}87.86 \pm 10.15 \\
72-120\end{array}$ & $\begin{array}{c}86.13 \pm 10.87 \\
68-120\end{array}$ \\
\hline 2 & B.P. (mmgh) Systolic & $113.36 \pm 6.68$ & $114-47 \pm 7.34$ & $117-7 \pm 7.73$ \\
& Mean \pm S.D. & $100-120$ & $110-130$ & $100-120$ \\
\hline \multirow{3}{*}{ Range } & Diastolic & $76 \pm 7.23$ & $76.53 \pm 6.40$ & $74.3 \pm 8.54$ \\
& Mean \pm S.D. & $70-90$ & $70-90$ & $40-90$ \\
\hline 3 & Range & & & \\
& Respiratory rate (per minute) & $19.46 \pm 1.96$ & $20.06 \pm 2.94$ & $21.86 \pm 6.07$ \\
& Mean \pm S.D. & $16-24$ & $16-30$ & $16-24$ \\
\hline
\end{tabular}

The estimates of cardiovascular parameter were found to be within the normal range. Mean value of respiratory rate definitely on higher side in patients of tuberculous pleural effusion.

CSF examination in tuberculous meningitis patients

The diagnosis of tuberculous meningitis was established by correlating the clinical finding with CSF changes in relation to physical examination.

TABLE : 8

PHYSICAL EXAMINATION OF CSF OF TUBERCULOUS MENINGITIS CASES

\begin{tabular}{|l|c|c|c|}
\hline Physical characteristic & Findings & No. of Cases & Percentage \\
\hline \multirow{2}{*}{ Appearance } & Clear & 28 & 93.33 \\
\cline { 2 - 4 } & Hazy & 2 & 6.66 \\
\hline \multirow{2}{*}{ Cobweb formation } & Present & 1 & 3.33 \\
\cline { 2 - 4 } & Absent & 29 & 96.66 \\
\hline
\end{tabular}

In the present study clear CSF was found in $93.33 \%$ cases hazy in $6.66 \%$ cases and cobweb formation was present in only one case. 
TABLE : 9

CSF ADA LEVELS IN RELATION TO CSF TOTAL LEUCOCYTE COUNT IN TUBERCULOUS MENINGITIS PATIENTS

\begin{tabular}{|l|c|c|c|}
\hline \multirow{2}{*}{ Group } & \multicolumn{2}{|c|}{ CSF Total Leucocyte Count / cumm } & \multirow{2}{*}{$\begin{array}{c}\text { ADA U/L } \\
\text { Mean + S.D }\end{array}$} \\
\cline { 2 - 3 } & Category & Means \pm S.D. & $5.87 \pm 4.12$ \\
\hline I $(n=8)$ & $<100$ & $2.62 \pm 1.76$ & $34.51 \pm 18.44$ \\
\hline II $(n-17)$ & $100-200$ & $137.41 \pm 36.08$ & $41.22 \pm 23.09$ \\
\hline III $(n=s)$ & $>200$ & $265.8 \pm 52.66$ & $27.99 \pm 21.34$ \\
\hline Entire $(n=30)$ & & $122.86 \pm 93.46$ & \\
\hline
\end{tabular}

Increased ADA activity corresponded to increased total leucocyte count indicating participation of cell mediated immunity.

TABLE : 10

CSF ADA LEVELS IN RELATION TO CSF PROTEINS IN TUBERCULOUS MENINGITIS PATIENTS

\begin{tabular}{|l|c|c|c|}
\hline \multirow{2}{*}{ Group } & \multicolumn{2}{|c|}{ CSF Protein mg/dL } & \multirow{2}{*}{$\begin{array}{c}\text { ADA U/L } \\
\text { Mean + S.D }\end{array}$} \\
\cline { 2 - 3 } & Category & Mean \pm S.D. & $5.87 \pm 4.12$ \\
\hline I (n=8) & $<100$ & $22.25 \pm 4.16$ & $28.62 \pm 15.84$ \\
\hline II (n-13) & $100-200$ & $142.68 \pm 32.04$ & $46.74 \pm 19.34$ \\
\hline III (n=9) & $>200$ & $358+42 \pm 164.54$ & $27.99 \pm 21.34$ \\
\hline Entire Series & $<100-\geq 200$ & $175.29 \pm 158.88$ & \\
\hline
\end{tabular}

The data revealed that with low CSF protein ADA activity was also low with increased in CSF protein level an approvable increase in ADA activity was observed.

TABLE : 11

CSF ADA LEVELS IN RELATION TO CSF GLUCOSE IN TUBERCULOUS MENINGITIS PATIENTS

\begin{tabular}{|l|c|c|c|}
\hline \multirow{2}{*}{ Group } & \multicolumn{2}{|c|}{ CSF Glucose mg/dL } & \multirow{2}{*}{ ADA U/L } \\
\cline { 2 - 3 } & Category & Mean + S.D. & $36.03 \pm 19.21$ \\
\hline I $(\mathrm{n}=22$ & $<40$ & $32.84 \pm 4.44$ & $5.87 \pm 4.12$ \\
\hline II $(\mathrm{n}-13)$ & $>40$ & $67.62 \pm 6.58$ & $27.99 \pm 21.34$ \\
\hline Entire III $(\mathrm{n}=30)$ & & $42.11 \pm 16.41$ & \\
\hline
\end{tabular}

Adenosine deaminase activity was clearly higher in group I patients with CSF glucose $<40 \mathrm{mg} / \mathrm{dL}$. The patients with higher glucose level (>40 mg/dL) showed normal ADA level.

Swartz et al. (7) reported decreased CSF glucose in patients with bacterial meningitis.

ADA is considered as a marker of cell mediated immunity. ADA is a polymorphic enzyme involved in purine metabolism, catalyses the deamination of adenosine to inosine and ammonium. Although found in most tissue, ADA activity is greatest in the lymphoid tissue, its activity being 10-20 times more active in T lymphocytes than in B lymphocytes. ADA plays a part in the differentiation of lymphid cells and the maturation of monocytes to macrophages. The congential and genetically determined deficit of this enzyme with its autosomal receive trait. It is reported to be associated with severe from of combined immuno deficiency and its responsible for an increase in toxic nucleotides that prevent the differentiation or proliferation (or both) of $\mathrm{T}$ lymphocytes and thus a normal immune function mediated by cells. The raising of the levels of ADA activity under antigenic stimulation shows the importance of this enzyme in the rapid proliferation of cells in order to prevent the accumulation of toxic metabolistis. Therefore, an increased ADA activity is present in several circumstances in pleural, pericardiac and peritoneal effusion of a tuberculous nature and in tuberculous cerebrospinal fluid, where ADA values are significantly higher than in normal group ad in other neurological disease.

TABLE : 12

ADA ACTIVITY IN RELATION TO NUTRITIONAL STATUS OF STUDY POPULATION

\begin{tabular}{|l|c|c|c|c|}
\hline Parameters & $\begin{array}{c}\text { Controls }(\mathbf{n}=\mathbf{3 0}) \\
\text { Mean } \pm \text { SD }\end{array}$ & $\begin{array}{c}\text { Tuberculous } \\
\text { meningitis }(\mathbf{n}=\mathbf{3 0}) \\
\text { Mean } \pm \text { SD }\end{array}$ & $\begin{array}{c}\text { Tuberculous pleural } \\
\text { effusion }(\mathbf{n}=\mathbf{3 0}) \\
\text { Mean } \pm \text { SD }\end{array}$ & $\begin{array}{c}\text { Tuberculous } \\
\text { ascities }(\mathbf{n}=\mathbf{3 0}) \\
\text { Mean } \pm \text { SD }\end{array}$ \\
\hline $\mathrm{BMI} \mathrm{kg/m} 2$ & $21.25 \pm 1.56$ & $18.06 \pm 3.06$ & $17.53 \pm 2.14$ & $17.92 \pm 2.71$ \\
\hline $\mathrm{Hb} \mathrm{gm} / \mathrm{dL}$ & $13.88 \pm 0.97$ & $11.03 \pm 1.97$ & $11.13 \pm 2.02$ & $10.37 \pm 1.44$ \\
\hline & Serum & $\mathbf{C S F}$ & Pleural fluid & Ascitic fluid \\
\hline $\mathrm{ADA} \mathrm{U} / \mathrm{L}$ & $14.05 \pm 4.02$ & $27.99 \pm 21.34$ & $75.32 \pm 40.12$ & $76.71 \pm 37.35$ \\
\hline
\end{tabular}

www.iosrjournals.org 
The observation revealed that the nutritional status of the study population as compared to the control group was poor; the mean BMI and mean $\mathrm{Hb}$ values of the tuberculous patients were significantly lower than the control group. The serum ADA level of the control group was well within the normal range on the contrary the ADA values of the respective body fluids measured in tuberculous patients were higher than the normal values for that specific fluid.

TABLE : 13

CORRELATION OF BMI \& ADA LEVEL IN THE STUDY POPULATION

\begin{tabular}{|l|c|c|c|c|}
\hline \multicolumn{1}{|c|}{ Group } & $\begin{array}{c}\text { BMI }\left(\mathbf{k g} / \mathbf{m}^{2}\right) \\
\text { Mean } \pm \text { S.D. }\end{array}$ & $\begin{array}{c}\text { ADA (U/L) } \\
\text { Mean } \pm \text { S.D. }\end{array}$ & 'r' & 'p' \\
\hline Male $(\mathrm{n}=45)$ & $19.08 \pm 2.65$ & $55.61 \pm 38.90$ & -0.369 & $<0.01$ \\
\hline Female $(\mathrm{n}=45)$ & $16.60 \pm 1.99$ & $64.40 \pm 42.15$ & -0.151 & Not significant \\
\hline
\end{tabular}

Malnutrition is well known to produce adverse effects on pulmonary function and immunological parameters. It is well established that malnutrition adversely affects the host immune response to mycobacterial infection. In the present study all the female subjects $(n=45)$ were malnourished as evident from the BMI values and dietary history. Being malnourished these patients are more prone to develop pulmonary malfunctions and antituberculous treatment induced hepatoxicity correlation of BMI \& ADA levels in the study population showed a negative association between the two indicating that poor nutritional status is responsible for aggravating the infection. The increased ADA levels suggest active immune response in these subjects. But if the nutrition of these patients is not improved it may adversely affect cellular immune response that is important for containing and restricting tuberculosis infection. Tuberculosis itself further deteriorates the nutritional status and predisposes to co-infection with HIV.

\section{Conclusion:}

In conclusion, the determination of ADA activity in CSF of TBM patients using cut off value of $>10$ $\mathrm{U} / \mathrm{L}$ and pleural fluid and ascitic fluid using cut off value of $>40 \mathrm{U} / \mathrm{L}$ can be useful for early diagnosis of these condition and it is cost effective being simple, cheaper and quicker serologic test. The delayed diagnosis is directly related to a poor prognosis the chemotherapy may be delayed until the patient is critically ill. This test provides a presumptive diagnosis of tuberculous meningitis, tuberculous pleural effusion and tuberculous ascites patients upon which to institute chemotherapy although it does not replace the standard cytological and microbiological diagnostic methods. This test may thus be useful in laboratories with limited resources, especially in underdeveloped and developing countries like India, where the incidence of tuberculosis is very high.

The body's immune system functions well in a nutritionally sound body. In nutritionally compromised patients the low ADA activity reflects the poor status of immune system. It is therefore suggested that utmost care should be taken to improve nutritional status of the tuberculosis patients so that cell mediated immunity help prevents the progress of the disease.

\section{References:}

[1]. Yoneda T. Nutritional status and support in chronic intractable pulmonary tuberculosis. Kekkaku. 1996 ;71(1):57-63.

[2]. Hanekom WA, Potgieter S, Hughes EJ, Malan H, Kessow G, Hussey GD. Vitamin A status and therapy in childhood pulmonary tuberculosis. J Pediatr 1997; 131:925-7.

[3]. Mehta JB, Fields CL, Byrd RB Jr. Roy. TM, Nutritional status and mortality in respiratory failure caused by tuberculosis. Tenn Med. $1996: 89: 369-71$

[4]. Macallan DC, MC Nurlan MA, Kurpad AV, de Souza G. Shetty PS. Falder AG et al. Whole body protein metabolism in human pulmonary tuberculosis and under nutrition evidence for anabolic block in tuberculosis. Clion Sci (Colch) $1998: 94: 321-31$.

[5]. Villegas MV Labrada LA, Saravia NG : Evaluation of polymerase chain reaction, adenosine deaminase, and interferon - $\square$ in pleural fluid for the differential diagnosis of pleural tuberculosis. Chest 2000; $118: 1355-1364$.

[6]. Aguado JM, Pons F, Alvarez S. Steigmann F. The enigma of tuberculous peritonitis. Gastroenterology 1990:550-4.

[7]. Swartz MN and Dodge PR. Bacterial meningitis - a review of resulted aspects. N. Engl. J. Med.1965; $272: 275$. 